\title{
Evidence for Financial Hierarchy Theory in Capital Structure Decisions: Data from BIST Companies
}

\author{
Elif Acar* \\ Adana Alparslan Türkeş Science and Technology University
}

\author{
Gamze Vural** \\ Çukurova University
}

\author{
Emin Hüseyin Çetenak*** \\ Niğde Ömer Halisdemir University
}

\begin{abstract}
The aim of this study is to test and expound the firm-level factors that determine financial leverage via testing a panel data of non-financial companies listed in the BIST throughout 1994-2015. We aim to build on our previous study of the same data set (Vural \& Acar, 2018), which tested the basic model of Financial Hierarchy theory via a simple regression analysis of financial leverage on financial deficit and yielded positive results at $1 \%$ significance level. In this study, using reliably significant factors of leverage, we further analyze the effects of firm characteristics on changes in leverage by using the system version of the Generalized Method of Moments (System GMM). Operational profitability and firm size are found to negatively affect debt levels, while market-to-book value ratio has a positive effect, as predicted by the Financial Hierarchy theory. The median industrial leverage ratio has a positive coefficient, more in line with Trade-off theory's predictions.
\end{abstract}

Keywords: Capital Structure, Financial Hierarchy, Trade-off, GMM.

JEL Classification: G320

\section{Sermaye Yapısı Kararlarında Finansman Hiyerarşisi Teorisinin Belirleyiciliği: BİST Firmaları Örneği}

$\ddot{\mathbf{O} z}$

$\mathrm{Bu}$ araştırmanın amacı finansal kaldıraç etmenlerini, BİST'e kayıtlı finans-dışı firmaların 1994-2015 yılları arasındaki verileri üzerinden test etmek ve Finansman Hiyerarşisi teorisinin beklentileri ışığında yorumlamaktır. Daha önce aynı veri seti üzerinde Finansman Hiyerarşisi teorisinin geçerliliğini temel aksiyomu üzerinden test ettiğimiz ve finansal açık ile kaldıraç oranı arasında \%1 düzeyinde anlamlı pozitif bağıntı bulduğumuz çalışmanın (Vural \& Acar 2018) sonuçları da buradaki bulgularla bir araya getirilerek yorumlanmıştır. Bu çalışmada Firma karakteristik özelliklerinin kaldıraç oranına etkisi, güvenilir bir şekilde anlamlı sonuçlar veren firmaya has değişkenler kullanılarak Genelleştirilmiş Momentler Metodu (GMM) ile

\footnotetext{
* Asst.Prof. Elif Acar, Adana Alparslan Türkeş Science and Technology University, Faculty of Business Administration, Department of Management Information Systems. E-mail: eacar@atu.edu.tr. ORCID: 00000003-0107-5517

** Assoc.Prof. Gamze Vural, Çukurova University, Faculty of Economics and Administrative Sciences, Department of Business Administration. E-mail: gvural@cu.edu.tr. ORCID: 0000-0002-1385-7551

*** Assoc.Prof. Emin Hüseyin Çetenak, Niğde Ömer Halisdemir University, Faculty of Economics and Administrative Sciences, Department of Banking and Finance. E-mail: cetenak@gmail.com. ORCID: 0000-0003-2900-4948
} 
analiz edilmiştir. Faaliyet karlılığı ve firma büyüklügünün borçlanma seviyesi üzerinde negatif etkili olduğu, büyüme olanaklarının göstergesi olarak alınan piyasa-defter değeri oranının ise pozitif etkili olduğu bulunmuştur. Bu bulgular Finansman Hiyerarşisi teorisinin tahminleri ile uyumludur. Endüstri kaldıraç oranı medyanı değişkeninin firma kaldıraç oranı üzerinde pozitif etkili olduğu sonucuna ulaşılmıştır $\mathrm{ki}$ bu bulgu daha ziyade Ödünleşme teorisiyle örtüşmektedir.

Anahtar Kelimeler: Sermaye Yapısı, Finansman Hiyerarşisi, Ödünleşme Teorisi, GMM. JEL Siniflandırmasi: G320

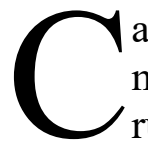

apital structure decisions encompass companies' debt-to-equity ratio choices, debt maturity choices and selection of various categories of debt and equity. As a general rule, company-value maximization is the ultimate goal of managers; hence companies want to find the right capital structure that will maximize their value.

In the early days of capital structure theories, researchers focused on the relationship between company-value and capital structure. However, these traditional capital structure approaches, namely Net Income and Net Operational Income, rooted in Durand's 1952 and 1959 papers, were challenged due to their simplistic view of the company level behavior and the financial environment. Furthermore, most researchers expressed interest in finding empirical evidence concerning capital structure decisions. Researchers also found the task of empirically testing the relationship between company value and debt levels daunting, because it was nearly impossible to hold constant the other factors that might affect company-value or general stock market price levels in an economy (Myers, 1984).

The modern research and theoretical framework more or less evolved from Modigliani \& Miller's (MM) 1958 and 1963 papers on capital structure. In their 1958 paper, MM stated that in a perfect economy under efficient market conditions where there are no bankruptcy or transaction costs and no information asymmetry, as long as no taxes were applied, firms belonging to the same type of industry-risk group and generating the same type of risky cash flows could not distinguish themselves from one another in terms of firm-value simply by changing their capital structure. This axiom came to be known as the 'irrelevance of capital structure'. Surely, they meant to indicate that, when firms operate in imperfect markets, capital structure does matter for a firm's value (Miller, 1989). Relaxing the "no taxes" assumption and allowing for corporate taxes to be applied, interest expense becomes tax-deductible and the cost of debt is significantly reduced compared to cost of equity. This would lead to $100 \%$ debtfinanced companies if the expected returns of each form of capital remained the same at any level of debt. However, we do know that the ability to pay back debt can be a significant risk factor for a company and it would not only raise the cost of equity at increased levels of borrowing but the cost of debt as well. Also, issuing equity and debt in imperfect financial markets have differing transaction costs associated with them, as well as differing signaling effects on investors. Hence, when taxes, bankruptcy risk, transaction costs, information asymmetry and agency costs are considered, choice of capital becomes quite important. Researchers expected these factors to have significant effects on the level of borrowing and began to focus on what determines the capital structure of companies in the real world. Such research yielded what we can call today's modern capital structure theories. Among the modern approaches to capital structure, Financial Hierarchy and Trade-off theories, including the Trade-off theory incorporating agency costs, have been the most distinguished with their empirically tested and approved fundamental propositions. 
In this study, we examine the effect of company characteristics on leverage levels in the framework of Financial Hierarchy and Tradeoff theories. Our motivation for this paper mostly stems from our previous research (Vural \& Acar, 2018) on the same set of data, establishing a positive relationship between financial deficit and leverage (a positive coefficient of 0.40), as formulated by Shyam-Sunder \& Myers in 1999. We had further tested this relationship by separating the effects of financial deficit and surplus on leverage, taking the example from De jong, Verbeek and Verwijmeren's 2010 study. In that case, our results showed a stronger significant positive relationship between leverage and financial deficit (a positive coefficient of 0.7). However, we found no evidence of debt repayment when there was a financial surplus, which contradicted the expectations of the Financial Hierarchy theory in its purest form. Therefore, we decided to further investigate the effects of firm characteristics and check if the results would fall in line with Financial Hierarchy theory's predictions. We have selected the factors based on Frank \& Goyal's 2009 study, which scanned a vast array of research that was carried out to determine firm-specific factors that affect leverage and attained a group of factors that reliably showed significant explanatory power, namely median industry leverage, marketto-book assets ratio, tangibility, profits, firm size, and expected inflation. Maintaining a firmspecific view, we have included the firm-specific reliable factors in our analysis and omitted the only macro-economic factor, expected inflation.

Our data sample includes data from 205 non-financial public companies in Turkey throughout the 1994 - 2015 period. We employed the same data that we used in our 2018 simple regression analysis testing the basic model of Financial Hierarchy for the sake of consistency and with the aim of building on the discussion of the applicability of Financial Hierarchy theory in explaining Turkish companies' capital structure decisions. The period covers a span of 20 years for the analyses to be robust. The time period includes boom and bust cycles in the economy, which will provide a through-it-all aspect to testing the validity of Financial Hierarchy predictions. Yet, an argument has been made regarding the limitation of this analysis, namely that it focuses only on long-term data without breaking the data set into subgroups of various time periods including or excluding crisis years, or categorizing the data based on firmspecific values such as firm size (small and large firms) or country of origin. Nevertheless, we would like to accept that argument as a limitation here and present this study as an extension of our previous research testing the validity of Financial Hierarchy Theory axioms over the given period's sample set of Turkish non-financial public companies.

\section{Framework of Capital Structure Theories}

Trade-off theory presumes that debt has a lower cost compared to equity based on higher expected returns for equity given its residual claim on the income and assets of a company. Especially when the tax-advantage of interest expense is considered, debt becomes a relatively low-cost source of capital. However, borrowing cannot be unlimited due to restrictions imposed by increasing default probability at higher levels of debt and looming bankruptcy costs. Hence, capital structure is determined as a result of the trade-off between the tax advantages of debt and financial distress costs. The axioms of this theory have been developed mainly by Kraus \& Litzenberger (1973), Miller (1977), and Myers (1984). Kraus \& Litzenberger (1973) stated that the optimal capital structure for a company is the one that balances the tax-advantages of debt and the cost of financial distress. Hence, depending on its business risk, each company will have a target optimal debt-to-equity ratio (Myers, 1984). This has come to be known as the static model of Trade-off theory. Later, dynamic models of the Trade-off theory that have since been introduced assume the optimal debt-to-equity ratio will be a moving target within a band (Fischer, Heinkel, \& Zechner, 1989; Hovakimian, Opler, \& Titman 2001). Aside from bankruptcy risk, Trade-off theory also considers factors that would 
increase or decrease the proportion of recovery and a company's position with respect to taxshields as the fundamental aspects that affect the target ratio of optimal leverage.

In conjunction with Trade-off theory's original axiom, in 1976 Jensen \& Meckling introduced the agency-cost perspective into the factors that affect borrowing decisions. The agency-cost perspective considers the benefits of debt stemming from eliminating the existing agency related problems between managers and shareholders, offset by the agency costs of debt that arise from the conflict between lenders and shareholders. Debt provides certain benefits; it can eliminate the free cash flow problem that could corrupt managers, and it can discipline managers to be more prudent in cash flow management to comply with debt repayment schedules. At the same time, increased levels of debt bring new costs arising from the conflict between lenders and shareholders, such as the adverse selection problem leading to devaluation of a company's securities by investors or stricter covenants imposed by lenders to have more control over the company. Hence, companies want to find the optimal level of borrowing that balances the above-mentioned agency-related benefits and costs of debt.

Alongside Trade-off theory, with a critical approach to its target debt-to-equity ratio concept, Financial Hierarchy theory began to spread its roots, based on some existing notions in the financial world and empirical evidence from companies. According to Myers \& Majluf (1984), evidence does not suggest that firms have a target debt-to-equity ratio that they move towards; rather, firms seem to follow a pecking order of capital sources based on their level of susceptibility to information asymmetry. Information asymmetry exists between company insiders and outside investors. Insiders know more about the company's risks and opportunities than the outsiders and the outsiders know that they are at a disadvantage when it comes to information. Hence, this causes outside investors to value a company's financial instruments at a discount most of the time. Companies not wanting to bear this cost when financing their investments, initially opt for internal sources of capital that carry no information asymmetry. If internal funds are insufficient, then they turn to external sources, first issuing debt securities with a relatively low information asymmetry, and finally issuing equity, which has the highest cost of information asymmetry. It is accepted, however, that when external funds are needed, borrowing cannot be unlimited. When funding requirements exceed a company's ability to borrow without changing its perceived risk by investors, the company will have to bear the cost of issuing equity. This proposition of borrowing capacity is inherent within and does not violate the axiom of Financial Hierarchy theory (Shyam-Sunder \& Myers, 1999; Lemmon \& Zender, 2010).

The original premise of Financial Hierarchy theory establishes a direct relationship between financial deficit and leverage. Financial deficit is defined as the difference between the current internal funds of a company and the current funding requirements given their investment and dividend expenditures. Shyam-Sunder \& Myers (1999) stated this relationship formulaically and tested it via a simple regression using the data of a group of public companies in the U.S.A. throughout the 1971-1989 periods. Their results indicated that financial deficit positively and significantly affects leverage. However, there were also criticisms of the study, especially regarding the fact that the simple regression between financial deficit and leverage neglected the effect of company characteristics on capital structure decisions (Frank \& Goyal, 2003; Fama \& French, 2002).

The expectations of Trade-off and Financial Hierarchy theories about the relationship between leverage and firm characteristics differ in most circumstances. Financial Hierarchy makes predictions about the expected relationship based on whether or not the information asymmetry will be exasperated or lowered with the level of the given firm characteristics, as well as the implications of the firm characteristic data for the availability of internal funds; i.e. 
the lower the information asymmetry, the higher the borrowing will be and the higher the availability of internal funds, the lower the leverage is expected to be. Trade-off theory views the relationship from a default risk and agency-cost perspective, i.e. if the firm characteristic data implies a low level of default risk and agency costs, then leverage is expected to increase.

We have summarized below the general predictions of the Financial Hierarchy theory in conjunction with the Trade-off theory predictions concerning the most reliable firm-specific factors for explaining changes in leverage as put forward by Frank \& Goyal (2009).

\section{i. $\quad$ Profitability and Leverage}

Financial Hierarchy expects a negative relationship. Profitable firms will have ample internal funds, therefore need to rely less on debt.

Trade-off theory expects a positive relationship. Profitability increases the ability to pay back debt and creates a bigger incentive to utilize debt's tax shielding advantage; therefore borrowing is expected to increase. From the agency-cost perspective the discipline provided by debt is beneficial for profitable firms since these firms are likely to suffer from free cash flow problems (Jensen, 1986).

\section{ii. $\quad$ Firm Size and Leverage}

Financial Hierarchy theory expects firm size to have a negative effect on leverage. As long as they are profitable, large firms would have high levels of internal funds; therefore these firms are not expected to be highly levered. At the same time, as firms get bigger, they provide more information to outside investors and the information asymmetry decreases with respect to equity issuance, making it a viable alternative to borrowing.

Trade-off theory expects firm size to have a positive effect on leverage. As total assets become larger and more diversified, these firms would benefit from diversification of risk with respect to the sources of their cash flow and be less likely to default. This would lead to the ability to borrow higher levels of debt.

\section{iii. $\quad$ Firm Age and Leverage}

Financial Hierarchy expects age to negatively affect leverage. Mature firms, like big firms, will suffer less from the negative effects of information asymmetry and the marginal cost of issuing equity would be lower for them. At the same time, if they are also profitable, they would have accumulated large amounts of internal funds and need less external financing.

Trade-off expects the age of a firm to have a positive effect on leverage. Mature firms will have better credibility in debt markets and face lower debt-related agency costs.

\section{iv. $\quad$ Growth Capacity and Leverage}

Financial Hierarchy expects growth capacity to have a positive effect on leverage, in general. As firms enter into a growth phase, their financing needs will increase and due to the increasing levels of information asymmetry associated with growth, equity-type securities will be costly. Therefore, these firms will tend to rely more on borrowing as an external source of financing. However, Myers (1984) makes an important distinction for small-sized, high-growth types of risky firms with limited borrowing capacities, and states that these types of firms will have to rely on equity to finance their growth. 
Trade-off expects a negative relationship between leverage and growth capacity. Growth opportunities increase financial distress, eat up free cash flow eliminating management's access to free-cash, and finally make a firm more susceptible to debt-related agency costs. Therefore, firms in high-growth phases are expected to finance themselves with equity. There is a distinction regarding growth capacity's effect on leverage from the trade-off theory's perspective as well. It is important to distinguish which type of investment expenditures the firm is undertaking with respect to growth in order to correctly predict the financing behavior. Renewal of existing assets would not necessarily increase default risk and could be financed with debt, whereas growth into new and risky ventures would be expected to be financed with equity (Shyam-Sunder \& Myers, 1999).

\section{v. Asset Tangibility and Leverage}

Financial Hierarchy expects the tangible-assets-to-total-assets ratio to have a negative relationship with leverage. Tangible assets have less information asymmetry associated with them and hence, decrease the cost of issuing new equity. Firms with high levels of tangible assets are expected to be levered low. According to Myers, they also tend to guard their valuable tangible assets from bankruptcy risk by not taking on too much debt; they have more to lose if default occurs.

Trade-off theory predicts a positive relationship. Tangible assets decrease default probability and increase recovery value, therefore firms with valuable tangible assets are able to better lever themselves.

\section{vi. Industry Leverage Ratios and Firm-Leverage}

Financial Hierarchy theory does not have a direct prediction about the relationship between mean or median industry leverage ratios and firm-leverage. However, an indirect inference can be made that the average borrowing level in the industry that the firm belongs to may be a good indicator of that firm's financing needs, therefore leading to an expectation of positive correlation between the two.

Trade-off theory clearly expects a positive relationship, since it predicts that firms will revert to the mean of their industry's average leverage ratio as the optimal borrowing level to be attained. Industry median leverage is thought to be used as a benchmark by managers to arrange their debt levels, and therefore used often as a proxy for the target debt ratio by researchers (Gilson, 1997; Hull, 1999; Hovakimian, et al., 2001; Faccio \& Masulis, 2005; Flannery \& Rangan, 2006).

\section{Literature}

Myers (1984) and Myers \& Majluf (1984) established the framework for Financial Hierarchy and Trade-off theories of capital structure. Following their theoretical framework, many researchers focused on the determinants of capital structure by means of analyzing company data and tried to verify the axioms of these theories focusing on the implications for company level behavior inherent in these axioms. For example, according to Myers (1984), Financial Hierarchy theory expects that companies with high profitability would be levered less because they would have more internal funds to rely on in order to finance their deficit. Furthermore, if they are not running a financial deficit but rather have a surplus of funds, then they would be inclined to pay-down debt, hence lowering leverage.

Shyam-Sunder \& Myers (1999) tested the Financial Hierarchy and Trade-off models based on their basic premises. They conducted a simple regression analysis, plotting the 
financial deficit of the firms (difference of investment expenditures minus internally generated free cash flow) against changes in leverage. They concluded that the Financial Hierarchy tested better, verifying a positive and strong relationship between leverage ratio and the financial deficit. This study later became a stepping-stone for discussions around the effect of firm characteristics and capital structure decisions, for it neglected to account for these factors.

Myers (2001) tried to identify where firm characteristic and financing behavior data overlapped with or dissociated from the theories of capital structure. Evidence of aggregate data showed that between 1980 and 2000, companies in the U.S. financed most of their investments with internal funds, e.g. depreciation expense and retained earnings. The aggregate data also indicated that internal funds were utilized before debt sources and borrowing was preferred over equity issuance for financing; even high-level borrowing occurred to buy back equity. However, Myers also stated that these general inferences were based on aggregate data and when company groupings were made, small-sized, risky and high-growth type companies relied more on equity financing than borrowing. In the same article, when firms were grouped by industry, the highly levered firms were mostly mature firms that had high tangible assets to total assets ratios. In general, firms with high profitability and risky investment opportunities that did not own substantial tangible assets carried less debt, sometimes even negative debt. These findings were in line with Trade-off theory's inferences, except for the high-profitability companies having low leverage ratios, which still needed to be explained.

According to Myers (2001), it is not right to say that only one theory of capital structure is always prevailing; rather, both Trade-off and Financial Hierarchy theories have explanatory power over financing behavior under different circumstances. He also stated that rather than testing the validity of these theories over aggregate data sets, it would be more prudent to group firms and analyze financing behavior based on firm characteristics.

Hovakimian, et al. (2001) state that firms will change their financing preference (debt vs. equity) according to the type of investment they are making; nevertheless, over time, their leverage ratios will converge towards a dynamic optimum leverage ratio - an ever changing optimum ratio in line with the changing conditions of the firm and its environment. They reported from their findings that firms prefer to use debt when financing their renewal of existing assets and revert to equity issuance for growth investments.

Fama \& French (2002) studied the relationship between firm characteristics and capital structure decisions as well as dividend policies, in the framework of Trade-off and Financial Hierarchy theories. They discovered that highly profitable firms with limited investment opportunities paid out more dividends and used less debt, whereas profitable firms with greater investment opportunities paid fewer dividends over the long run and only changed their dividend policy to adjust to short-term changes in investment opportunities. Further, short-term deficits between earnings and investments were mostly financed with debt. All of these findings suggest that firms revert to financing behavior in line with Financial Hierarchy theory in the short-run and make their capital structure decisions in line with Trade-off theory in the longrun.

Frank \& Goyal (2003) tested the Financial Hierarchy theories' inferences about the relationship between leverage and financial deficit, adding to the mix firm characteristics such as asset tangibility, market-to-book value ratio, sales growth and profitability by employing the data of U.S. public companies over an extended period from 1971 through 1998. Furthermore, they grouped firms according to size, with the prediction that firms' financing needs and capacity will vary significantly by size. As a result, they reported that Financial Hierarchy behavior is valid among large-size firms but not enough evidence is found for small-size firms. 
They also concluded that when the data set is divided into various time periods, Financial Hierarchy theory's applicability to explain financing behavior diminishes after 1990 .

Frank \& Goyal (2009), in an effort to identify the most important firm characteristic factors that affect leverage, analyzed the effects of 20 parameters that stand out in the literature and concluded that six of these firm characteristics have the most explanatory power in defining capital structure decisions. Those factors and their effect on leverage are: Industry leverage ratios' median that positively affects leverage, market-to-book ratio with a negative effect, asset tangibility with a positive effect, asset profitability with a negative effect, firm size with a positive effect, and expected inflation with a positive effect.

Lemmon \& Zender (2010) stated that Shyam-Sunder and Myers's (1999) model, albeit incomplete, carries an important assumption that is often neglected in criticisms of the model. In their hypothesis that firms finance themselves according to a pecking order of available funds based on the level of information asymmetry, Shyam-Sunder and Myers do not exclude the concept of borrowing capacity. Rather, they state that firms with high borrowing capacity will finance their incremental deficits via borrowing and when the borrowing capacity is exceeded, they will have to issue equity to balance their capital structure and financial risk. Hence, Lemmon \& Zender (2010) extended the basic model of Financial Hierarchy to include borrowing capacity, using firms' credit ratings as an indication of that. When they categorized firms based on their credit ratings, they found that the ones with high borrowing capacity did indeed yield better results in the simple regression analysis of Financial Hierarchy theory. Therefore, they concluded that their results were in accordance with the Financial Hierarchy theory's suggestion that firms fund their incremental financing needs via borrowing when they have the borrowing capacity and when the borrowing capacity is exceeded, they issue new equity.

De Jong, Verbeek, \& Verwijmeren (2011) tested the Trade-off theory against the Financial Hierarchy theory while focusing on an important difference in prediction: the Tradeoff theory argues that a firm increases leverage until it reaches its target debt ratio, while the financial hierarchy yields debt issuance until debt capacity is reached. This is assuming, of course, that the target debt ratio and debt capacity are different from each other, the latter being higher than the former. By employing a sample of U.S firms with investment-grade ratings throughout 1985-2005, they found out that financial hierarchy is a better descriptor of firms' issue (deficit) decisions than the Trade-off theory. In contrast, Trade-off theory is a stronger predictor of firms' capital structure decisions about repurchase (surplus).

Fan, Titman, \& Twite (2012) studied the effects of firm characteristics as well as external factors on borrowing decisions. When firm characteristics and leverage relationship was analyzed across the 39 countries included in the study, they found that asset tangibility and firm size positively affected leverage, whereas profitability and market-to-book ratio negatively affected debt levels.

Graham, Leary, \& Roberts (2015) pointed out the observable changes in a firm's borrowing decisions over the last sixty years that cannot be explained by the existing theories of capital structure. Especially in the U.S., the leverage ratios of firms in general have been increasing since 1945, which cannot be explained by a correlating trend in firm characteristics or industry-wide changes. As a result, they determined that government borrowing in capital markets and increase in intermediation services in financial markets are the two most important external factors to explain the overall increase in leverage ratios in the private sector.

The literature after 2015 continues with numerous studies of empirical research covering the relatively under-examined sections of the global economy, including the less 
developed regions of the world, small and medium size enterprises, and cross-country analyses (Serrasqueiro \& Caetano, 2015; Balios, Daskalakis, Eriotis, \& Vasiliou, 2016; Kumar \& Rao, 2017; Muritala, 2018).

We have provided a summary of relevant research conducted on Turkish companies in the past 15 years in Table 1. As seen in Table 1, for Turkish companies, more often than not, profitability is found to have a negative effect on leverage, similar with the results of our study and consistent with Financial Hierarchy predictions. Thus, as companies generate more internal funds with increased profitability, they rely less on borrowing. On the other hand, other firmspecific determinants usually indicate a consistency with Trade-off theory's predictions, e.g. asset tangibility and firm size having positive effects on leverage and growth having a negative effect. In contrast, our results from this study mostly confirmed Financial Hierarchy predictions. The only seemingly contradicting result was the positive effect of Mean Industry Leverage on Firm-Leverage; researchers in the past have documented evidence of strong industry effects in debt ratios, which they interpret as evidence of optimal ratios (Shyam-Sunder and Myers, 1999).

Table $1 \quad$ Summary of Relevant Research from Turkey

\begin{tabular}{|c|c|c|c|c|c|}
\hline $\begin{array}{l}\text { Authors (Year } \\
\text { Published) }\end{array}$ & Sample Data & $\begin{array}{l}\text { Method of } \\
\text { Analysis }\end{array}$ & Factors Tested & $\begin{array}{l}\text { Effect on } \\
\text { Leverage }\end{array}$ & $\begin{array}{l}\text { Implied } \\
\text { Theory }\end{array}$ \\
\hline \multirow{5}{*}{$\begin{array}{l}\text { Sayılgan, } \\
\text { Karabacak, \& } \\
\text { Küçükkocaoğlu } \\
(2006)\end{array}$} & \multirow{5}{*}{$\begin{array}{l}\text { Public } \\
\text { Manufacturing } \\
\text { Companies, } \\
\text { 1993-2002 }\end{array}$} & \multirow{5}{*}{$\begin{array}{l}\text { Panel Data } \\
\text { Regression }\end{array}$} & Firm size & Positive & Trade-off \\
\hline & & & Profitability & Negative & $\begin{array}{l}\text { Financial } \\
\text { Hierarchy }\end{array}$ \\
\hline & & & Growth rate & Positive & $\begin{array}{l}\text { Financial } \\
\text { Hierarchy }\end{array}$ \\
\hline & & & Asset tangibility & Not significant & - \\
\hline & & & Tax shields & Not significant & - \\
\hline \multirow[t]{3}{*}{ Akkaya (2008) } & \multirow{3}{*}{$\begin{array}{l}\text { Leather and } \\
\text { Textile } \\
\text { Manufacturers, } \\
1997-2006\end{array}$} & \multirow[t]{3}{*}{$\begin{array}{l}\text { Simple } \\
\text { Regression }\end{array}$} & $\begin{array}{l}\text { Asset } \\
\text { Profitability }\end{array}$ & Positive & Trade-off \\
\hline & & & Growth rate & Negative & Trade-off \\
\hline & & & Firm size & Positive & Trade-off \\
\hline \multirow[t]{5}{*}{$\begin{array}{l}\text { Terim and } \\
\text { Kayalı (2009) }\end{array}$} & \multirow{5}{*}{$\begin{array}{l}\text { Public } \\
\text { Manufacturing } \\
\text { Companies, } \\
\text { 2000-2007 }\end{array}$} & \multirow[t]{5}{*}{$\begin{array}{l}\text { Panel Data } \\
\text { Regression }\end{array}$} & Asset tangibility & Affective & - \\
\hline & & & Profitability & Affective & - \\
\hline & & & $\begin{array}{l}\text { Tax shield other } \\
\text { than debt }\end{array}$ & Not significant & - \\
\hline & & & Firm size & Not significant & - \\
\hline & & & Growth capacity & Not significant & - \\
\hline $\begin{array}{l}\text { Okuyan and } \\
\text { Taşçı (2010) }\end{array}$ & $\begin{array}{l}\text { First } 1.000 \\
\text { Industrial } \\
\text { Firms, 1993- } \\
2007\end{array}$ & $\begin{array}{l}\text { Panel Data } \\
\text { Regression }\end{array}$ & $\begin{array}{l}\text { Firms prefer } \\
\text { financing with } \\
\text { internal funds } \\
\text { first, and then } \\
\text { borrowing. }\end{array}$ & - & - \\
\hline \multirow{4}{*}{$\begin{array}{l}\text { Ata and } \mathrm{Ag} \\
(2010)\end{array}$} & \multirow{4}{*}{$\begin{array}{l}\text { Public } \\
\text { Companies in } \\
\text { Metals and } \\
\text { Machinery } \\
\text { Industries, } \\
\text { 2003-2007 }\end{array}$} & \multirow{4}{*}{$\begin{array}{l}\text { Panel Data } \\
\text { Regression }\end{array}$} & Liquidity ratio & Negative & - \\
\hline & & & $\begin{array}{l}\text { Interest cov. } \\
\text { ratio }\end{array}$ & Negative & - \\
\hline & & & Firm size & Positive & Trade-off \\
\hline & & & Growth capacity & Negative & Trade-off \\
\hline
\end{tabular}




\begin{tabular}{|c|c|c|c|c|c|}
\hline $\begin{array}{l}\text { Authors (Year } \\
\text { Published) }\end{array}$ & Sample Data & $\begin{array}{l}\text { Method of } \\
\text { Analysis }\end{array}$ & Factors Tested & $\begin{array}{l}\text { Effect on } \\
\text { Leverage }\end{array}$ & $\begin{array}{l}\text { Implied } \\
\text { Theory }\end{array}$ \\
\hline \multirow{6}{*}{$\begin{array}{l}\text { Sarioğlu, Kurun, } \\
\text { \& Güzeldere } \\
\text { (2013) }\end{array}$} & \multirow{6}{*}{$\begin{array}{l}\text { Public } \\
\text { Companies in } \\
\text { Cement, Auto } \\
\text { and IT } \\
\text { Industries, } \\
\text { 2007-2011 }\end{array}$} & \multirow[t]{6}{*}{$\begin{array}{l}\text { Panel Data } \\
\text { Regression }\end{array}$} & Growth rate & Positive & $\begin{array}{l}\text { Financial } \\
\text { Hierarchy }\end{array}$ \\
\hline & & & Firm size & Positive & Trade-off \\
\hline & & & Asset tangibility & Positive & Trade-off \\
\hline & & & Liquidity & Not significant & - \\
\hline & & & Tax shields & Not significant & - \\
\hline & & & Profitability & Not significant & - \\
\hline \multirow{9}{*}{$\begin{array}{l}\text { Köksal and } \\
\text { Orman (2015) }\end{array}$} & \multirow{9}{*}{$\begin{array}{l}9.000 \text { Public } \\
\text { and Non- } \\
\text { public } \\
\text { Companies, } \\
\text { 1994-2014 }\end{array}$} & \multirow{9}{*}{$\begin{array}{l}\text { Panel Data } \\
\text { Regression }\end{array}$} & Firm size & Positive & Trade-off \\
\hline & & & Tax shields & Positive & - \\
\hline & & & Industry lev. & Positive & Trade-off \\
\hline & & & Asset tangibility & Positive & Trade-off \\
\hline & & & Profitability & Negative & $\begin{array}{l}\text { Financial } \\
\text { Hierarchy }\end{array}$ \\
\hline & & & Business risk & Negative & Trade-off \\
\hline & & & GDP & Negative & - \\
\hline & & & Inflation & Negative & - \\
\hline & & & $\begin{array}{l}\text { Growth } \\
\text { opportunities }\end{array}$ & Not significant & - \\
\hline
\end{tabular}

\section{Methodology}

We are building on our previous study on the same set of data (Vural \& Acar, 2018), which aimed to test the validity of Financial Hierarchy theory, by testing the relationship between financial deficit and leverage, as formulated by Shyam-Sunder \& Myers in 1999. Based on the basic premise of the hierarchy model, firms are expected to finance the deficit of funds from operations minus investment expenditures plus dividend payments (i.e. "sticky dividends") by incurring debt, and pay back debt when there is a surplus of funds. This proposition obligates that there be a positive and one-to-one relationship between financial deficit (or surplus) and increase (or decrease) in leverage. In our 2018 study, a two-step regression analysis was carried out via the System GMM method of testing. First, the implied positive relationship between debt level and financial deficit was tested using the following model:

$$
\Delta \operatorname{Lev}_{\mathrm{i}, \mathrm{t}}=\alpha+\beta_{0} \mathrm{DEF}_{\mathrm{i}, \mathrm{t}}+\varepsilon_{\mathrm{i}, \mathrm{t}}
$$

Financial deficit was defined as follows:

$$
\mathrm{DEF}_{\mathrm{i}, \mathrm{t}}=\left(\mathrm{Div}_{\mathrm{i}, \mathrm{t}}+\mathrm{I}_{\mathrm{i}, \mathrm{t}}-\mathrm{CFO}_{\mathrm{i}, \mathrm{t}}\right) / \mathrm{TA}_{\mathrm{i}, \mathrm{t}}
$$

$\Delta \operatorname{Lev}_{\mathrm{i}, \mathrm{t}}$ : Change in leverage,

$\operatorname{Lev}_{\mathrm{i}, \mathrm{t}}$ : Book value of total short and long-term debt divided by total assets,

$\mathrm{TA}_{\mathrm{i}, \mathrm{t}}$ : Book value of total assets,

$\operatorname{Div}_{\mathrm{i}, \mathrm{t}}$ : Cash dividend payments,

$\mathrm{I}_{\mathrm{i}, \mathrm{t}}:$ Net investment expenditures,

$\mathrm{CFO}_{\mathrm{i}, \mathrm{t}}$ : Net cash flow from operations, including change in working capital.

The coefficient of the financial deficit was found to be positive and 0.4 , at $1 \%$ significance level. 
Table 2 Results of the Pre-Analysis: Model Run of $\Delta$ Leverage over Financial Deficit

\begin{tabular}{|c|c|c|c|c|c|}
\hline $\begin{array}{l}\text { Independent } \\
\text { Variables: }\end{array}$ & $\bar{\beta}$ & $\begin{array}{l}\text { Robust } \\
\text { Std. Err. }\end{array}$ & $\mathrm{z}$ & $\mathrm{P}>|\mathrm{z}|$ & \\
\hline DEFICIT & $0.399 * * *$ & 0.047 & 8.49 & 0.000 & \\
\hline ***1\% signi & ance level & & & & Wald $\operatorname{chi}^{2}(1): 72.06$ \\
\hline$* * 5 \%$ signifi & nce level & & & & Prob. $>$ chi $^{2}: 0,000$ \\
\hline \multicolumn{6}{|c|}{ Arellano-Bond test for AR(1) in first differences: $\mathrm{z}=-6.69 \operatorname{Pr}>\mathrm{z}=0.000$} \\
\hline \multicolumn{6}{|c|}{ Arellano-Bond test for $\mathrm{AR}(2)$ in first differences: $\mathrm{z}=-0.88 \operatorname{Pr}>\mathrm{z}=0.381$} \\
\hline \multicolumn{6}{|c|}{ Hansen test of overid. restrictions: $\operatorname{chi} 2(86)=56.08$ Prob $>$ chi $2=0.99$} \\
\hline
\end{tabular}

Next, separate effects of financial deficit and surplus were tested using a dummy variable in the model as follows:

$$
\Delta \operatorname{Lev}_{\mathrm{i}, \mathrm{t}}=\alpha+\beta_{1} \times \mathrm{d}_{\mathrm{i}, \mathrm{t}}+\beta_{\mathrm{DEF}} \times \mathrm{DEF}_{\mathrm{i}, \mathrm{t}}+\beta_{\mathrm{SUR}} \times \mathrm{d}_{\mathrm{i}, \mathrm{t}} \times \mathrm{DEF}_{\mathrm{i}, \mathrm{t}}+\varepsilon_{\mathrm{i}, \mathrm{t}}
$$

$\mathrm{d}_{\mathrm{i}, \mathrm{t}}$ : Dummy variable; its value is 1 when $\mathrm{DEF}_{\mathrm{i}, \mathrm{t}}<0$ (there is surplus), otherwise 0 .

Table 3 Results of the Pre-Analysis: Model Run of $\Delta$ Leverage over Financial Deficit and Financial Surplus Separately

\begin{tabular}{lllll|l}
\hline $\begin{array}{l}\text { Independent } \\
\text { Variables: }\end{array}$ & $\beta$ & $\begin{array}{l}\text { Robust } \\
\text { Std. Err. }\end{array}$ & $\mathrm{z}$ & $\mathrm{P}>|\mathrm{z}|$ & \\
\hline DEF & $0.669 * * *$ & 0.1892 & 3.54 & 0.000 & \\
SUR & -0.816 & 0.4651 & -1.76 & 0.079 & \\
$\begin{array}{l}\text { SUM OF DEF } \\
\text { \& SUR }\end{array}$ & -0.147 & & & \\
\hline$* * * 1 \%$ significance level & & & Wald chi ${ }^{2}$ (3): 51.39 \\
$* * 5 \%$ significance level & & & Prob. $>$ chi2: $0,000^{*}$
\end{tabular}

Arellano-Bond test for AR(1) in first differences: $\mathrm{z}=-5.70 \operatorname{Pr}>\mathrm{z}=0.000$

Arellano-Bond test for $\operatorname{AR}(2)$ in first differences: $z=-1.10 \operatorname{Pr}>z=0.270$

Hansen test of overid. restrictions: $\operatorname{chi} 2(170)=151.18$ Prob $>\operatorname{chi} 2=0.847$

The positive coefficient between the borrowing and pure financial deficit increased to 0.7 at $1 \%$ significance level, signifying the validity of Financial Hierarchy types of choices when firms need to use external financing. However, the coefficient of the financial surplus was negative, i.e. Turkish firms do not pay down debt when they have a surplus of internal funds. A possible explanation for this may be Turkish companies' reluctance to lower debt with the fear of not being able to access those funds again. In Turkish capital and money markets, private sector debt instruments' transaction numbers and volume in the primary market are incomparably low against the other more developed markets registered with the World Federation of Exchanges (Türkiye Sermaye Piyasası Meclisi Sektör Raporu, 2011, TOBB, p. 7-8). With limited access to public markets, companies revert to the banking sector for borrowing needs, which has higher intermediation costs compared to capital markets 
borrowing in general (Lemmon \& Zender, 2010). Furthermore, the banking sector experiences frequent liquidity constraints in Turkey. These types of constraints on funds available for borrowing could provide incentive for companies to hold onto borrowed funds even when they have a surplus of cash. Obviously, to attain a conclusive reason for reluctance to pay down debt when there is surplus would require further modeling and testing of these hypotheses.

Given the indefinite results from our analysis, as well as the large body of literature criticizing the simplistic model of Financial Hierarchy for neglecting other factors that affect leverage, we decided to further investigate the effects of firm characteristics and check if the results would verify Financial Hierarchy theory's predictions.

In this study we have analyzed the data from 205 Turkish public companies, excluding the ones in the financial sector, over a 20-year period via panel data analysis. Generalized Method of Moments (GMM), specifically the system version of GMM, is one of the dynamic models of panel data analyses developed by Holtz-Eakin, Newey, \& Rosen, (1988), Arellano \& Bond (1991), Arellano \& Bover (1995), and Blundell \& Bond (1998). Dynamic models are ones where the dependent variable's lagged values take place as an independent variable in the model. In dynamic models, the endogenous variable problem may occur if an independent variable is correlated with the error term, and the lagged value of the dependent variable may sometimes cause this problem, leading to inconsistent results. The GMM method has been designed to eliminate such problems (Roodman, 2006). GMM and its system version have begun to be used more and more in economics and finance research due to their ability to control for reverse causality, error term related problems, and omitted variable bias (Dökmen, 2012) in a direct manner.

In our analysis, at first static models of panel data were used to test the selected variables' effect on leverage, then a GMM system estimator was used. When compared, the results were quite close and the system GMM provided a more direct way of conducting the analyses.

\section{The model}

$$
\Delta \mathrm{LEV}_{\mathrm{i}, \mathrm{t}}=\mathrm{a}+\mathrm{b}_{1} \text { EBITDA }_{\mathrm{i}, \mathrm{t}}+\mathrm{b}_{2} \operatorname{LnTA}_{\mathrm{i}, \mathrm{t}}+\mathrm{b}_{3} \mathrm{M} / \mathrm{B}_{\mathrm{i}, \mathrm{t}}+\mathrm{b}_{4} \mathrm{NFA}_{\mathrm{i}, \mathrm{t}}+\mathrm{b}_{5} \operatorname{INDLEV}_{\mathrm{i}, \mathrm{t}}+\varepsilon_{\mathrm{i}, \mathrm{t}}
$$

All variables are scaled by Total Assets book value at time $t$.

- $\Delta \mathrm{LEV}_{\mathrm{i}, \mathrm{t}}$ : The difference between the current year leverage ratio $\left(\mathrm{LEV}_{\mathrm{t}}\right)$ and the previous year leverage ratio $\left(\mathrm{LEV}_{\mathrm{t}-1}\right)$,

- $\quad \mathrm{LEV}_{\mathrm{i}, \mathrm{t}}$ : Total of short-term and long-term debt book value divided by book value of total assets, measure of profitability,

EBITDA $_{\mathrm{i}, \mathrm{t}}$ : Earnings before interest, taxes, depreciation and amortization as a

- $\quad \operatorname{LnTA}_{\mathrm{i}, \mathrm{t}}$ : Natural logarithm of total assets as a measure of firm-size,

- $\quad \mathrm{M} / \mathrm{B}_{\mathrm{i}, \mathrm{t}}$ : The total of market capital value and total debt book value over book value of total assets, as a proxy measure of growth capacity,

- $\quad \mathrm{NFA}_{\mathrm{i}, \mathrm{t}}$ : Net fixed assets as a measure of asset tangibility,

- $\quad$ INDLEV $_{\mathrm{i}, \mathrm{t}}$ : The median leverage ratio of the firms' industry, which is classified by a two-digit SIC code.

\section{The Data}

We have presented in Table 4 the descriptive statistics of the variables used in the study. The average leverage ratio for the sample is quite low at $22.5 \%$. A reason for this low leverage may be the relatively higher interest rates in the economy during the sample years and the limited 
availability of funds for borrowing in direct capital markets. Turkey's private sector bond issuance is low; it has been argued that this could be due to government bonds' crowding effect and a low level of savings in the economy. Most companies borrow from the banks. Another noteworthy data point is the high net fixed assets ratio, which can be attributed to the sample consisting mostly $(80 \%)$ of manufacturing and industrial firms. Note: The data is not clipped at top and bottom $1 \%$.

Table 4 Descriptive Statistics of the Variables

\begin{tabular}{|c|c|c|c|c|c|c|}
\hline Variable & Mean & Median & Std. Dev. & $\begin{array}{l}\text { Lowest } \\
25 \%\end{array}$ & $\begin{array}{l}\text { Highest } \\
25 \%\end{array}$ & $\begin{array}{l}\text { Highest } \\
1 \%\end{array}$ \\
\hline Leverage & 22.5 & 16.90 & 32.38 & 3.57 & 32.90 & 89.30 \\
\hline$\Delta$ Leverage & 0.01 & 0 & 15.61 & -3.56 & 4.15 & 34.21 \\
\hline Fin. Deficit & 27.53 & 17.36 & 15.08 & -3.70 & 8.57 & 43.43 \\
\hline Profitability & 14.66 & 12.02 & 21.69 & 5.85 & 21.54 & 60.55 \\
\hline Firm Size & 11.92 & 11.89 & 1.83 & 10.66 & 12.96 & 16.39 \\
\hline M/B Ratio & 1.14 & 0.72 & 1.55 & 0.42 & 1.26 & 8.67 \\
\hline $\begin{array}{l}\text { Net Fixed } \\
\text { Assets }\end{array}$ & 33.96 & 33.34 & 19.79 & 18.54 & 48.06 & 81.25 \\
\hline $\begin{array}{l}\text { Industry Lev. } \\
\text { Median }\end{array}$ & 19.57 & 17.82 & 13.85 & 9.10 & 28.43 & 61.23 \\
\hline
\end{tabular}

Table 5 presents the correlation matrix of the variables employed in the model, as well as the financial deficit variable that was modeled separately. The highest correlation with the dependent variable (change in leverage) belongs to profitability. As predicted by the Financial Hierarchy theory, this relationship is an inverse one, i.e. a negative correlation.

Table 5 Correlation Matrix of the Variables Employed in the Model

\begin{tabular}{lccccccc}
\hline & $\Delta$ Leverage & $\begin{array}{c}\text { Fin. } \\
\text { Deficit }\end{array}$ & Profitability & $\begin{array}{c}\text { Firm } \\
\text { Size }\end{array}$ & $\begin{array}{c}\mathrm{M} / \mathrm{B} \\
\text { Ratio }\end{array}$ & $\begin{array}{c}\text { Net } \\
\text { Fixed } \\
\text { Assets }\end{array}$ & $\begin{array}{c}\text { Industry } \\
\text { Leverage } \\
\text { Median }\end{array}$ \\
\hline$\Delta$ Leverage & 1.00 & & & & & & \\
Fin. Deficit & 0.29 & 1.00 & & & & & \\
Profitability & -0.14 & 0.26 & 1.00 & & & & \\
Firm Size & 0.03 & 0.07 & 0.17 & 1.00 & & & \\
M/B Ratio & -0.08 & 0.03 & 0.22 & -0.15 & 1.00 & & \\
Net Fixed Assets & 0.03 & 0.06 & -0.05 & -0.01 & 0.01 & 1.00 & \\
Industry Leverage & 0.08 & 0.11 & -0.20 & 0.03 & -0.13 & 0.06 & \\
Median & & & & & & & \\
\hline
\end{tabular}




\section{Analysis Results}

We have tested the effects of firm-specific factors that are expected to affect leverage based on the premises of the Financial Hierarchy theory. The results of the GMM system tests are presented in Table 6. The Hansen test of over-identifying restrictions and the Arellano-Bond diagnostic tests were executed for the adequacy of the estimated model. The $p$ value of the Hansen test is insignificant so the null hypothesis that the instruments as a group are exogenous cannot be rejected. As expected, test for AR(1) in first difference rejects the null hypothesis that there is no autocorrelation. However, the test of $\operatorname{AR}(2)$ in first difference does not reject the null hypothesis. The output presents no significant evidence of serial correlation in the firstdifferenced errors at order 2 .

Table 6 System GMM Test Results

\begin{tabular}{|c|c|c|c|c|c|}
\hline $\begin{array}{l}\text { Independent } \\
\text { Variables: }\end{array}$ & $\beta$ & $\begin{array}{l}\text { Robust } \\
\text { Std. Err. }\end{array}$ & $\mathrm{Z}$ & $\mathrm{P}>|\mathrm{z}|$ & Implied Theory \\
\hline Profitability & $-0.507 * * *$ & .0413865 & -12.25 & 0.000 & Financial Hierarchy \\
\hline Firm Size & $-0.008 * *$ & .0036224 & -2.09 & 0.036 & Financial Hierarchy \\
\hline M/B Ratio & $0.007 * *$ & .0030113 & 2.36 & 0.018 & Financial Hierarchy \\
\hline $\begin{array}{l}\text { Net Fixed } \\
\text { Assets }\end{array}$ & -0.023 & .0508948 & -0.44 & 0.659 & Not Significant \\
\hline $\begin{array}{l}\text { Industry } \\
\text { Leverage } \\
\text { Median }\end{array}$ & $0.246^{* * *}$ & .064617 & 3.80 & 0.000 & Trade-off \\
\hline \multicolumn{4}{|c|}{ ***1\% significance level } & & Wald $\operatorname{chi}^{2}(5): 297.27$ \\
\hline \multicolumn{4}{|c|}{$* * 5 \%$ significance level } & & Prob. $>$ chi $2: 0,000$ \\
\hline \multicolumn{6}{|c|}{ Arellano-Bond test for AR(1) in first differences: $\mathrm{z}=-7.27 \operatorname{Pr}>\mathrm{z}=0.000$} \\
\hline \multicolumn{6}{|c|}{ Arellano-Bond test for AR(2) in first differences: $\mathrm{z}=-1.17 \operatorname{Pr}>\mathrm{z}=0.242$} \\
\hline \multicolumn{6}{|c|}{ Hansen test of overid. restrictions: $\operatorname{chi} 2(84)=95.09$ Prob $>$ chi $2=0.192$} \\
\hline
\end{tabular}

As seen in Table 6, our analysis yielded statistically significant results for Profitability, Firm Size, Growth Opportunity (M/B Value) and Industry Median Leverage variables, while the Net Fixed Assets variable did not yield statistically significant results. A more detailed interpretation of the results is presented below.

\section{Firm Characteristics' Effects on Leverage Found \\ Profitability}

We found that profitability has a negative and relatively strong effect on the level of leverage, consistent with the Financial Hierarchy theory prediction that profitable firms experience an increase in available internal funds and rely less on borrowing. This finding violates the expectation of the Trade-off theory that profitable firms would increase leverage because of increased borrowing capability and incentive to use debt as a tax shield. However, it should be noted that Trade-off theory does not necessarily automatically predict that profitability leads to tax shield requirements; it is important to investigate whether companies have forms of tax shields other than debt. Highly profitable firms with high depreciation and amortization expenses, investment tax incentives or previous years' losses, which can all serve as tax shields 
other than debt, tend to have lower leverage levels compared to similar profitable firms (DeAngelo \& Masulis, 1980; Graham \& Tucker, 2006; Huizinga, Laeven, \& Nicodeme, 2008).

From the agency-cost perspective of Trade-off theory, high profitability leading to high levels of free cash flow means companies would lever themselves up in order to benefit from the disciplining effects of debt repayment on management. However, this predicament may not be true for Turkish public companies in the industrial and manufacturing sectors, because according to the Capital Markets Board of Turkey Report from June 2018, most public firms in Turkey are managed by majority shareholders themselves.

\section{Firm Size}

We found that firm size has a negative yet weak effect on leverage, which is in line with Financial Hierarchy expectations because as firms get bigger, as long as they remain profitable, they generate more internal funds and need less external funding. Bigger firms are also expected to provide more information to investors and decrease their equity-issuance costs stemming from information asymmetry.

The findings related to firm size are not in line with the expectation of Trade-off theory, which infers that bigger firms that are generally profitable and low-risk can, and would, incur more debt.

\section{Growth Capacity}

We found that market-to-book value ratio, which is taken as a proxy to denote growth capacity, has a positive effect on leverage. This finding is compatible with the Financial Hierarchy prediction that firms in growth phases will have increased financing needs and due to the amplified level of information asymmetry associated with growth, equity-type securities will be costly. Therefore, these firms will tend to rely more on borrowing as an external source of financing. In addition, Myers' (1984) important distinction for "small-sized, high-growth type of risky firms with limited borrowing capacity having to rely on equity to finance their growth" has a footing here, since the sample is mostly comprised of companies with opposing features.

According to Trade-off theory's expectation, growth capacity should negatively affect leverage since growth is accompanied by increasing financial distress costs, a decreasing free cash flow problem from an agency-cost perspective, and renders the firms more sensitive to debt related agency costs. Therefore, growth is expected to be financed with equity according to the Trade-off model.

\section{Asset Tangibility}

Net fixed assets did not yield significant results in our analysis.

\section{Industry Median Leverage}

We found a positive and significant effect of the Industry leverage ratio on firm-level leverage. Financial Hierarchy theory does not have a direct prediction about the relationship between mean or median industry leverage ratios and firm-leverage. However, an indirect inference can be made that the average borrowing level in the industry that the firm belongs to may be a good indicator of that firm's financing needs, therefore leading to an expectation of positive correlation between the two. 
Trade-off theory clearly expects a positive relationship, since it predicts that firms will revert to the mean of their industry's leverage ratios as the optimal borrowing level to be attained.

\section{Conclusion}

The results here, combined with the results of our previous analysis (Vural \& Acar, 2018) establishing a strong positive relationship between leverage and financial deficit, compel us to conclude that Financial Hierarchy predictions are more consistent with the capital structure decisions of Turkish companies, especially when in need of external funds. Nevertheless, no evidence for de-levering during financial surplus times was found. The repayment of debt when there is a financial surplus is part of the Financial Hierarchy axiom. According to capital structure discussions in the western literature, companies are expected to desire financial slack (unused debt capacity) for future opportunities and financial flexibility (Graham and Harvey, 2001). Nevertheless, we found no evidence of this behavior for BIST companies in Turkey.

The firm-level factors' effects on leverage mostly confirm Financial Hierarchy predictions. Out of the five factors we have investigated, four yielded meaningful results and three of them pointed in the direction of Financial Hierarchy. Profitable firms used less debt, possibly relying on internal funds first, as predicted by Financial Hierarchy; larger size firms also used less debt possibly owing to their ability to generate internal funds and expectedly lower cost of information asymmetry, which could give them access to equity markets at decreased costs. Finally we found that market-to-book value ratio, which is taken as a proxy to denote growth capacity, has a positive effect on leverage. This finding is compatible with the Financial Hierarchy prediction that firms in their growth phases will have increased financing needs and due to the amplified level of information asymmetry associated with growth, equitytype securities will be costly. Therefore, these firms will tend to rely more on borrowing as an external source of financing.

There is indirect evidence in favor of Trade-off theory as well. We found a positive and significant effect of the Industry leverage ratio on firm-level leverage, which is in line with Trade-off theory's expectation that firms will revert to the mean of their industry's leverage ratios as the optimal borrowing level to be attained. Nevertheless, this finding does not necessarily violate Financial Hierarchy's predictions either. Financial Hierarchy theory does not have a direct prediction about the relationship between mean or median industry leverage ratios and firm-leverage. However, an indirect inference can be made that the average borrowing level in the industry may be a good indicator of the firm's financing needs, therefore leading to an expectation of positive correlation between the two.

In light of the findings from previous empirical studies and our own analyses, we conclude that Financial Hierarchy theory goes a long way in explaining the capital structure decisions of Turkish public companies, especially in financial deficit situations. However, we believe there is also room for Trade-off theory, esp. to explain the sticky leverage ratios particularly persistent through financial surplus conditions. This line of thinking is parallel with Myers' (1984) suggestion and Lemmon \& Zender's (2010) findings.

Further analyses can be conducted at the firm level to test the cogency of Financial Hierarchy theory in explaining the capital structure decisions in Turkish companies. Subgroupings of the companies based on firm size or other firm-level characteristics that are significant to the theory's predictions, as well as period divisions, can be possible areas of interest in further analyses that aim to calibrate their explanation of capital structure decisions of Turkish companies. 


\section{References}

Akkaya, C. G. (2008). Sermaye yapısı, varlık verimliliği ve karlılık: İMKB'de faaliyet gösteren deri-tekstil sektörü işletmeleri üzerine bir uygulama. Erciyes Üniversitesi İktisadi ve İdari Bilimler Fakültesi Dergisi, 30(1), 1-13.

Arellano, M., \& Bond, S. (1991). Some tests of specification for panel data: Monte Carlo evidence and an application to employment equations. The Review of Economic Studies, 58(2), 277-297.

Arellano, M., \& Bover, O. (1995). Another look at the instrumental variable estimation of errorcomponents models. Journal of Econometrics, 68(1), 29-51.

Ata, H. A. \& Ağ, Y. (2010). Firma karakteristiğinin sermaye yapısı üzerindeki etkisinin analizi. İstanbul Üniversitesi İktisat Fakültesi Ekonometri ve İstatistik Dergisi, 11(1), 45-60.

Balios, D., Daskalakis, N., Eriotis, N., \& Vasiliou, D. (2016). SMEs capital structure determinants during severe economic crisis: The case of Greece. Cogent Economics \& Finance, 4(1), 1145535.

Blundell, R., \& Bond, S. (1998). Initial conditions and moment restrictions in dynamic panel data models. Journal of Econometrics, 87(1), 115-143.

DeAngelo, H., \& Masulis, R. W. (1980). Optimal capital structure under corporate and personal taxation. Journal of Financial Economics, 8(1), 3-29.

De Jong, A., Verbeek, M., \& Verwijmeren, P. (2010). The impact of financing surpluses and large financing deficits on tests of the pecking order theory. Financial Management, $39(2), 733-756$.

De Jong, A., Verbeek, M., \& Verwijmeren, P. (2011). Firms' debt-equity decisions when the static tradeoff theory and the pecking order theory disagree. Journal of Banking ve Finance, 35(5), 1303-1314.

Dökmen, G. (2012). Yolsuzlukların vergi gelirleri üzerindeki etkisi: Dinamik panel veri analizi. Doğuş Üniversitesi Dergisi, 13(1), 41-51.

Durand, D. (1952, January). Costs of debt and equity funds for business: trends and problems of measurement. In Conference on research in business finance (pp. 215-262). NBER.

Durand, D. (1959). The cost of capital, corporation finance, and the theory of investment: comment. The American Economic Review, 49(4), 639-655.

Faccio, M., \& Masulis, R. W. (2005). The choice of payment method in European mergers and acquisitions. The Journal of Finance, 60(3), 1345-1388.

Fama, E. \& French, K. (2002). Testing trade-off and pecking order predictions about dividends and debt. Review of Financial Studies, 15(1), 1-33. 
Fan, J. P., Titman, S., \& Twite, G. (2012). An international comparison of capital structure and debt maturity choices. Journal of Financial and Quantitative Analysis, 47(1), 23-56.

Fischer, E. O., Heinkel, R., \& Zechner, J. (1989). Dynamic capital structure choice: Theory and tests. The Journal of Finance, 44(1), 19-40.

Frank, M. Z., \& Goyal, V. K. (2003). Testing the pecking order theory of capital structure. Journal of Financial Economics, 67, 217-248.

Frank, M. Z., \& Goyal, V. K. (2009). Capital structure decisions: which factors are reliably important? Financial Management, 38(1), 1-37.

Flannery, M. J., \& Rangan, K. P. (2006). Partial adjustment toward target capital structures. Journal of Financial Economics, 79(3), 469-506.

Graham, J. R., \& Harvey, C. R. (2001). The theory and practice of corporate finance: Evidence from the field. Journal of Financial Economics, 60(2-3), 187-243.

Graham, J. R., Leary, M. T.,\& Roberts, M. R. (2015). A century of capital structure: The leveraging of corporate America. Journal of Financial Economics, 118(3), 658-683.

Graham, J. R., \& Tucker, A. L. (2006). Tax shelters and corporate debt policy. Journal of Financial Economics, 81(3), 563-594.

Gilson, S. C. (1997). Transactions costs and capital structure choice: Evidence from financially distressed firms. The Journal of Finance, 52(1), 161-196.

Holtz-Eakin, D., Newey, W., \& Rosen, H. S. (1988). Estimating vector autoregressions with panel data. Econometrica: Journal of the Econometric Society, 56(6), 1371-1395.

Hovakimian, A., Opler, T. \& Titman, S. (2001). The Debt - Equity Choice. Journal of Financial and Quantitative Analysis, 36(1), 1-24.

Hull, R. M. (1999). Leverage ratios, industry norms, and stock price reaction: An empirical investigation of stock-for-debt transactions. Financial Management, 28(2), 32-45.

Huizinga, H., Laeven, L., \& Nicodeme, G. (2008). Capital structure and international debt shifting. Journal of Financial Economics, 88(1), 80-118.

Jensen, M. C. \& Meckling, W. H. (1976). Theory of the firm: Managerial behavior, agency costs and ownership structure. Journal of Financial Economics, 3(4), 305-360.

Jensen, M. C. (1986). Agency costs of free cash flow, corporate finance, and takeovers. American Economic Review, 76(2), 323-329.

Köksal, B., \& Orman, C. (2015). Determinants of capital structure: evidence from a major developing economy. Small Business Economics, 44(2), 255-282.

Kraus, A. \& Litzenberger, R. H. (1973), A state-preference model of optimal financial leverage. The Journal of Finance, 28, 911-922. 
Kumar, S., Colombage, S., \& Rao, P. (2017). Research on capital structure determinants: a review and future directions. International Journal of Managerial Finance, 13(2), 106132.

Lemmon, M. L., \& Zender, J. F. (2010). Debt capacity and tests of capital structure theories. Journal of Financial and Quantitative Analysis, 45(5), 1161-1187.

Miller, Merton. H. (1977). Debt and taxes. Journal of Finance. 32(2), 261-275.

Miller, M. H. (1989). The Modigliani-Miller propositions after thirty years. Journal of Applied Corporate Finance, 2(1), 6-18.

Modigliani, F., \& Miller M. H. (1958). The cost of capital, corporation finance and the theory of investment. American Economic Review, 48(3), 261-297.

Modigliani, F., \& Miller M. H. (1963). Corporation income taxes and the cost of capital: A correction. American Economic Review, 53(3), 433-443.

Muritala, T. A. (2018). An empirical analysis of capital structure on firms' performance in Nigeria. International Journal of Advances in Management and Economics, 1(5), 116124.

Myers, S. C. (1984). The capital structure puzzle. The Journal of Finance, 34(3), 575-592.

Myers, S. C,. \& Majluf, N. (1984). Corporate financing and investment decisions when firms have information that investors do not have. Journal of Financial Economics, 13(2), $187-221$.

Myers, S. C. (2001). Capital structure. Journal of Economic Perspectives, 15(2), 81-102.

Okuyan, H. A. \& Taşçı, H. M. (2010). Sermaye yapısının belirleyicileri: Türkiye'deki en büyük 1000 sanayi işletmesinde bir uygulama. BDDK Bankacılık ve Finansal Piyasalar Dergisi, 4(1), 105-120.

Roodman, D. (2006). How to do xtabond2: An introduction to "Difference" and "System" GMM in Stata. Center for Global Development Working Paper, 103.

Sarığlu, S. E., Kurun, E., \& Güzeldere, H. (2013). Sermaye yapısının belirleyicileri: İMKB'de işlem gören çimento, otomotiv ve bilişim sektörlerinin sermaye yapısı analizi. Ege Akademik Bakış Dergisi, 13(4), 481-496.

Sayılgan, G., Karabacak, H., \& Küçükkocaoğlu, G. (2006). The firm-specific determinants of corporate capital structure: Evidence from Turkish panel data. Investment Management and Financial Innovations, 3(3), 125-139.

Serrasqueiro, Z., \& Caetano, A. (2015). Trade-Off Theory versus Pecking Order Theory: capital structure decisions in a peripheral region of Portugal. Journal of Business Economics and Management, 16(2), 445-466. 
Shyam-Sunder, L., \& Myers, S. C. (1999). Testing the trade-off against pecking order models of capital structure. Journal of Financial Economics, 51, 219-244.

Terim, B., \& Kayalı, C. A. (2009). Sermaye yapısını belirleyici etmenler: Türkiye'de imalat sanayi örneği. Celal Bayar Üniversitesi Sosyal Bilimler Enstitüsü Sosyal Bilimler Dergisi, 7(1), 125-154.

Türkiye Sermaye Piyasası Meclisi Sektör Raporu, 2008, Türkiye Odalar ve Borsalar Birliği, Mart, 2008; TOBB Yayını Sira No: 2008/68.

Türkiye Sermaye Piyasası Meclisi Sektör Raporu, 2011, Türkiye Odalar ve Borsalar Birliği, Eylül, 2012; TOBB Yayını Sıra No: 2012/169.

Vural, G., \& Acar, E. (2018). Firma borçlanma kararlarında finansman hiyerarşisi kuramının geçerliliği: BIST firmaları üzerine ampirik bir analiz. Mersin Üniversitesi Uluslararası Katılımlı 22. Finans Sempozyumu Tam Metin Bildiri Kitapçı̆̆l, 1, 501-530. (Yayın No: 4509553) 